ABDIMAS: Jurnal Pengabdian Masyarakat Universitas Merdeka Malang
Vol.7(1) February 2022, 187-196
U-ISSN: 2721-138X e-ISSN: 2548-7159
Uttp://jurnal.unmer.ac.id/index.php/jpkm

\title{
The development of capability to create online learning with i-Spring Application for English teachers
}

\section{Pengembangan kemampuan menciptakan pembelajaran online dengan Aplikasi i-Spring bagi para guru Bahasa Inggris}

\author{
Hartono Hartono, Nani Hidayati \\ Departemen Pendidikan Bahasa Inggris, Universitas Islam Sultan Agung (UNISSULA) Semarang \\ Jl. Kaligawe Km 4 Semarang, 50112, Indonesia
}

\begin{abstract}
ARTICLE INFO:
\section{ABSTRACT}

Received: 2021-08-24

Revised: 2021-10-15

Accepted: 2021-12-20

COVID-19 pandemic has changed the lives of the global society. Education is among the sectors which are seriously affected. To contain the fast-spreading of COVID-19 and to protect students and teachers from being infected, temporarily schools were closed. Teaching and learning were conducted online from home. This new teaching and learning paradigm has brought a lot of challenges to teachers who were not familiar yet with the nature of online learning. To assist English teachers, a Team of Community Service from the Department of English Education Universitas Islam Sultan Agung (UNISSULA) organized a training to help them design online learning materials using the iSpring application. The training was attended by English teachers of Madrasah Aliyyah (MA) in Demak Regency as the members of the English Teachers Association popularly known as MGMP. The training covered presentation and workshops conducted offline at MA Negeri Demak under a strict implementation of health protocols. Offline training was followed by home assignments and online consultations between the teachers and the Team from the university. The training ran well and was very useful for the teachers to improve their ability in designing online learning materials.
\end{abstract}

(C) 2022 Abdimas: Jurnal Pengabdian Masyarakat Universitas Merdeka Malang This is an open access article distributed under the CC BY-SA 4.0 license (https://creativecommons.org/licenses/by-sa/4.0/)

How to cite: Hartono, H., \& Hidayati, N. (2022). The development of capability to create online learning with i-Spring Application for English teachers. Abdimas: Jurnal Pengabdian Masyarakat Universitas Merdeka Malang, 7(1), 187-196. https://doi.org/10.26905/abdimas.v7i1.6271

\section{PENDAHULUAN}

Virus korona (corona virus disease/COVID-19) yang di Indonesia mulai menyebar sejak Maret 2020 dan menjadi pandemi di banyak negara telah mengubah pola kehidupan masyarakat global (Hagerty \& Williams, 2020), Pendidikan adalah satu di antara sektor kehidupan yang sangat terdampak. Pola kehidupan para pelaku pendidikan dan pengajaran yaitu guru, dosen, mahasiswa, dan siswa di seluruh dunia sangat terpengaruh (Day et al., 2021; Nicola et al., 2020). Untuk menekan penyebaran COVID-19 dan untuk melindungi siswa dan guru dari bahaya infeksi, untuk sementara sekolah-sekolah ditutup. Pembelajaran tatap muka dengan interaksi langsung antara guru dan siswa di kelas dialihkan 
ABDIMAS: Jurnal Pengabdian Masyarakat Universitas Merdeka Malang

Volume 7, No 1, February 2022: 187-196

menjadi pembelajaran dalam jaringan (daring) dengan menggunakan beragam aplikasi. Pemerintah, melalui Menteri Pendidikan dan Kebudayaan, melalui Surat Edaran Nomor 36962/MPK.A/HK/2020 memberlakukan pembelajaran daring dan meminta pegawai, guru, dan dosen melaksanakan aktivitas bekerja, mengajar, dan memberi kuliah dari rumah (Bekerja dari Rumah/BDR) melalui video conferencing, digital documents, dan sarana pembelajaran daring lainnya. Hal ini dilakukan sebagai upaya pencegahan terhadap perkembangan dan penyebaran COVID-19 (Arifa, 2020).

Pembelajaran daring mensyaratkan banyak perubahan komponen pembelajaran dan pengajaran, baik menyangkut pembelajar (siswa), pengajar (guru), juga pengembangan materi (Kebritchi et al., 2017). Peran dan cara mengajar guru, peran dan cara belajar siswa, dan juga peran orang tua berubah. Meskipun telah berjalan sejak Maret 2020, berdasarkan pengamatan, masih banyak guru dan siswa belum siap melakukan pembelajaran daring secara baik. Sebuah penelitian yang melibatkan 257 responden dari DKI Jakarta, Provinsi Banten, dan Provinsi Jawa Barat menunjukkan bahwa hanya ada $14,78 \%$ responden yang siap melaksanakan pembelajaran daring, sementara 70,42\% kurang siap dan sisanya (14,39\%) bahkan tidak siap (Prabowo et al., 2020). Tetapi karena tidak ada cara lain maka dengan segala kesulitan dan hambatannya, pembelajaran daring ini tetap dilaksanakan.

Pada awal-awal pelaksanaannya banyak kisah menarik, lucu, dan menyedihkan terjadi dalam proses belajar mengajar. Ada kegagapan pendidik dan sekolah dalam merespon kebijakan pembelajaran daring. Ada orang tua yang stres karena harus mendampingi anak-anak belajar di rumah di sela-sela melaksanakan tugas rutinnya. Banyak pula siswa yang bingung menghadapi dan mengerjakan tugas dari para guru. Rupanya memberikan instruksi dan penugasan adalah pilihan yang paling banyak dilakukan oleh para guru karena pengetahuan dan ketrampilan mereka di bidang teknologi informasi yang rendah (Titi \& Sumarni, 2020). Akibatnya, siswa mengeluh dan menghadapi kenyataan bahwa belajar dari rumah jauh lebih berat dibandingkan dengan belajar di sekolah. Untuk itu evaluasi dan upaya-upaya perbaikan perlu segera dilakukan, dan program-program peningkatan kemampuan guru perlu segera disusun dan dijalankan. Hal ini karena, meskipun nanti situasi kembali normal dan sekolah kembali beraktivitas seperti semula, pembelajaran daring akan tetap dibutuhkan.

Ada 3 hal yang perlu segera dibenahi terkait dengan pelaksanaan pembelajaran daring ini. Yang pertama adalah kemampuan guru menyiapkan materi yang bisa dipahami sekaligus bisa "dinikmati" siswa. Banyak guru menghadapi masalah-masalah yang di antaranya adalah ketidakmampuannya menggunakan teknologi, kurangnya fasilitas sekolah yang mendukung pelaksanaan pembelajaran daring, kesulitannya menyajikan bahan ajar, dan lain-lain (Lestiyanawati \& Widyantoro, 2020). Materi untuk pembelajaran daring seharusnya tidak semata-mata teks buku yang disalin kemudian dikirimkan ke siswa melalui internet atau telepon pintar, dan siswa harus membaca, memahami sendiri, dan mengerjakan latihan sendiri. Karena dalam pembelajaran daring, interaksi siswa dengan guru terbatas, maka materi pembelajaran seharusnya dipersiapkan lebih baik, misalnya dengan menyertakan gambargambar, diagram, ataupun suara (audio) dan video sehingga materi tersebut bisa lebih mendorong dan memudahkan siswa untuk memahami isi (Handayani, 2020).

Yang kedua adalah bagaimana menyajikan materi tersebut. Di sini penguasaan teknologi berperan sangat penting. Guru diharapkan menguasai teknologi informasi dan komunikasi (ICT) yang bisa dimanfaatkan untuk pembelajaran. Layanan teknologi ini ada yang berbayar, artinya untuk dapat menggunakannya harus membayarnya, dan juga yang tidak berbayar. Guru, siswa, dan siapa saja yang ingin memanfaatkan teknologi itu bisa melakukannya selama mereka mempunyai alat seperti komputer atau telepon pintar yang terhubung dengan internet.

Permasalahan ketiga terkait dengan assessment atau pentaksiran luaran pembelajaran. Permasalahan-permasalahan teknis bagaimana melakukannya, tingkat kompleksitas latihan dan soal, peng- 
urutan soal-soal tersebut (sequencing), dan sejenisnya adalah beberapa permasalahan yang harus segera dicarikan solusinya (Gillett-swan, 2017). Pada kondisi normal dimana siswa dan guru bertemu di ruang kelas, evaluasi pembelajaran bisa dilaksanakan dalam bentuk tes. Siswa mengerjakan soal-soal yang diberikan secara individu dan tidak boleh meminta dan atau menerima bantuan dari siswa lain. Guru bisa leluasa mengawasi, menegur, bahkan memberi sanksi atas pelanggaran. Ketika pembelajaran dilakukan di rumah, hal ini tidak bisa dilakukan. Meskipun mungkin bisa dilakukan upaya-upaya seperti mendorong siswa untuk bekerja secara mandiri, tetapi guru tidak bisa memonitor dan mengontrol hal ini sepenuhnya. Dengan demikian, format tes untuk pembelajaran di rumah semestinya berbeda dengan format yang digunakan untuk pembelajaran kelas.

Guru-guru yang tergabung dalam MGMP Bahasa Inggris Madrasah Aliyyah (MA) Kabupaten Demak juga menghadapi berbagai kendala sebagaimana disebutkan di atas. Kemampuan IT dari sebagian besar guru yang masih rendah, sarana prasarana yang kurang mencukupi, dukungan sekolah yang masih perlu ditingkatkan, serta kurangnya akses terhadap pembiayaan dan pelatihan menjadikan para guru kurang bisa melakukan inovasi dan pengembangan kemampuan pelaksanaan pembelajaran. Sebagai contoh, survei pra-kegiatan yang dilakukan oleh tim pengabdi menemukan bahwa WhatsApp masih menjadi aplikasi yang paling banyak digunakan. Sementara ceramah menjadi strategi pembelajaran yang paling banyak diterapkan. Akibatnya pembelajaran yang dilaksanakan cenderung berjalan satu arah dan kurang bisa menarik perhatian dan minat belajar siswa (engaging). Hal ini memprihatinkan karena akan sangat berdampak pada kualitas luaran pembelajaran yaitu capaian pembelajaran siswa.

Atas dasar pertimbangan tersebut, Tim Pengabdi Prodi Pendidikan Bahasa Inggris Universitas Islam Sultan Agung (UNISSULA) mengajak MGMP Bahasa Inggris MA Kabupaten Demak sebagai Mitra kegiatan pengabdian. Dengan demikian tim pengabdi akan bisa membantu para guru. Tim pengabdi dan mitra memutuskan untuk mengangkat topik pengembangan kemampuan pembuatan bahan ajar pembelajaran daring melalui pelatihan iSpring yang merupakan sebuah aplikasi yang bisa dipergunakan para guru untuk mengembangkan materi pembelajaran interaktif. Dengan perangkat ini, materi pembelajaran bisa didesain dan disajikan dengan cara yang lebih menyenangkan dengan penambahan suara (audio), gambar hidup (video), kuis interaktif, dan lain-lain (Fadillah et al., 2021). Penelitian juga menunjukkan bahwa penggunaan iSpring bisa meningkatkan motivasi belajar siswa (Anwar et al., 2019) dan membantu peserta didik belajar sesuai dengan gaya belajarnya (Jannah et al., 2020). Relevan dengan hal tersebut, program pengabdian ini bertujuan untuk meningkatkan kemampuan para guru MGMP Bahasa Inggris Kabupaten Demak dalam membuat materi pembelajaran daring dengan aplikasi iSpring.

\section{METODE}

\section{Rancangan kegiatan}

Berdasarkan masalah yang timbul, tim pengabdi menyusun rancangan kegiatan dalam bentuk tahapan mulai dari persiapan kegiatan pengabdian ini hingga selesai. Rancangan ini selanjutnya dipergunakan sebagai pedoman pelaksanaan kegiatan. Rancangan tersebut disusun sebagaimana disajikan di Gambar 1.

Uraian kegiatan program pengabdian kepada masyarakat yang dilaksanakan adalah sebagai berikut: (1) Analisa kondisi objek PKM. Tim pengabdi mengadakan survei dan wawancara kepada mitra pengabdian yaitu ketua dan beberapa anggota MGMP Bahasa Inggris MA Kabupaten Demak yang merupakan target pelaksanaan program pengabdian. Hal ini untuk mengumpulkan informasi terkait kebutuhan materi pelatihan yang dibutuhkan oleh peserta pelatihan; (2) Persiapan konsep dan administrasi kerjasama. Tim pengabdi melakukan koordinasi dan persiapan kegiatan pengabdian dan 
ABDIMAS: Jurnal Pengabdian Masyarakat Universitas Merdeka Malang

Volume 7, No 1, February 2022: 187-196

pengajuan permohonan kerjasama dari mitra kepada Fakultas Bahasa dan Ilmu Komunikasi Universitas Islam Sultan Agung Semarang; (3) Survei kebutuhan materi pelatihan. Tim pengabdi melakukan survei terbatas guna mengidentifikasi kebutuhan mitra. Dari survei tersebut diperoleh informasi bahwa dalam pelaksanaan pengajaran banyak guru yang hanya mengunakan metode ceramah dan pengerjaan soal latihan dari buku. Sedikit sekali guru yang bisa menyusun materi ajar dengan kombinasi teks, video, dan audio yang interaktif. Atas dasar ini, Tim pengabdi memutuskan untuk memberi pelatihan pembuatan bahan ajar interaktif dengan aplikasi iSpring; (4) Pembuatan modul. Tim pengabdi menyusun modul pelatihan pembuatan bahan ajar interaktif dengan iSpring. Modul ini nantinya akan dibagikan kepada peserta dalam bentuk cetak. Modul berisi tahapan-tahapan proses dan contoh-contoh sehingga akan dapat dipahami dan dipraktikkan dengan mudah. Seperti penambahan suara dan gambar bergerak pada Power Point, dialog simulasi, screen recording, pembuatan kuis, dan lain-lain.

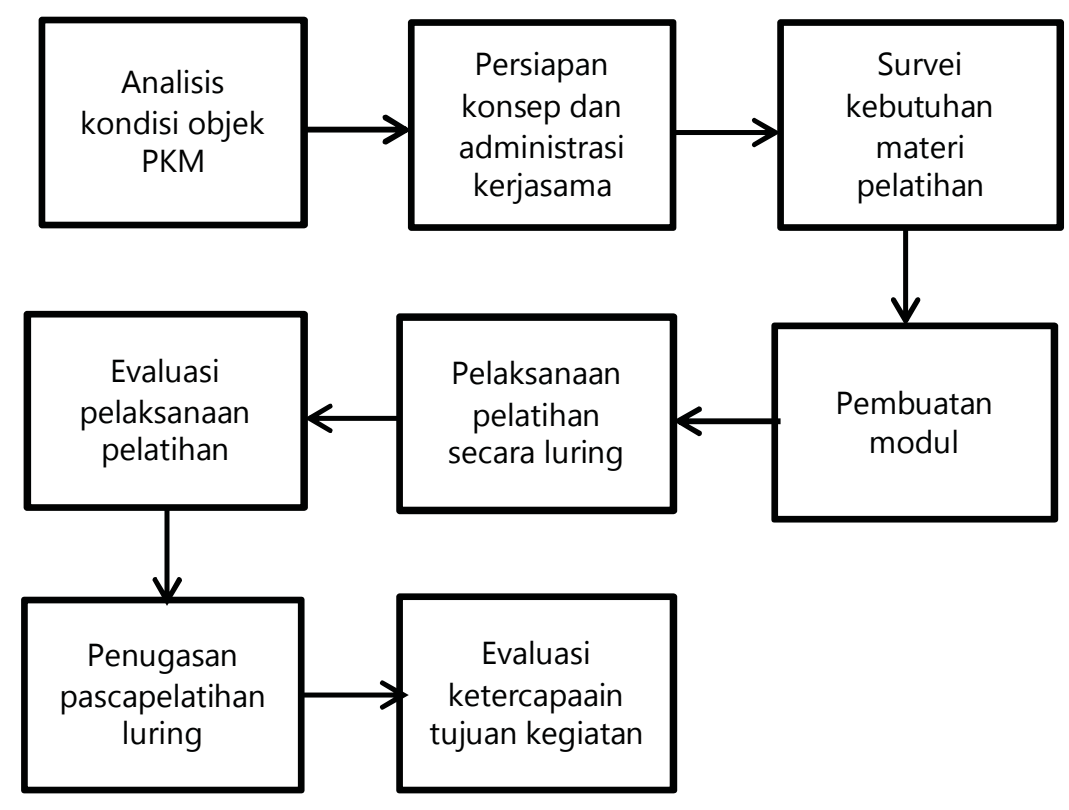

Gambar 1. Tahapan kegiatan

Tahap selanjutnya yang dilakukan adalah: (5) Pelatihan. Tim pengabdi menyelenggarakan pelatihan pembuatan materi pembelajaran daring dengan aplikasi iSpring secara luring. Kegiatan pelatihan mencakup presentasi, tanya jawab, dan workshop; (6) Evaluasi kegiatan. Tim pengabdi membagikan kuesioner kepada peserta pelatihan untuk mendapatkan umpan balik atas pelaksanaan pelatihan sebagai bahan evaluasi untuk perbaikan kegiatan pelatihan di masa mendatang; (7) Penugasan pasca pelatihan luring. Karena keterbatasan waktu pelatihan luring, kegiatan pelatihan dilanjutkan dengan penugasan di rumah (home assignment). Tim pengabdi membuka konsultasi secara daring untuk para peserta; (8) Evaluasi ketercapaian tujuan kegiatan. Tim pengabdi dan mitra (MGMP) melakukan evaluasi ketercapaian tujuan kegiatan secara bersama-sama.

\section{Metode}

Kegiatan pelatihan dilaksanakan dengan metode pemaparan (presentasi) dan tanya jawab, workshop, dan penugasan di rumah. Secara lebih detail kegiatan dan metodenya disajikan di Tabel 1. 


\section{The development of capability to create online learning with i-Spring Application for English teachers Hartono Hartono, Nani Hidayati}

Tabel 1. Rangkaian kegiatan pelatihan

\begin{tabular}{|c|c|c|}
\hline Materi & Metode & Durasi \\
\hline $\begin{array}{l}\text { Pemaparan dan praktik pembuatan bahan ajar daring dengan menggu- } \\
\text { nakan template tampilan yang menarik dari aplikasi iSpring }\end{array}$ & $\begin{array}{l}\text { Presentasi, tanya jawab, } \\
\text { workshop }\end{array}$ & $1 \times 45$ menit \\
\hline $\begin{array}{l}\text { Pemaparan dan praktik pembuatan bahan ajar daring dengan meng- } \\
\text { gunakan dialogue simulation iSpring }\end{array}$ & $\begin{array}{l}\text { Presentasi, tanya jawab, } \\
\text { workshop }\end{array}$ & $1 \times 45$ menit \\
\hline $\begin{array}{l}\text { Pemaparan dan praktik pembuatan bahan ajar daring dengan menyelip- } \\
\text { kan rekaman audio maupun video penjelasan materi langsung di } \\
\text { Power Point }\end{array}$ & $\begin{array}{l}\text { presentasi, tanya jawab, } \\
\text { workshop }\end{array}$ & $2 \times 45$ menit \\
\hline $\begin{array}{l}\text { Pemaparan dan praktik pembuatan bahan evaluasi bahan ajar daring } \\
\text { dengan quiz iSpring }\end{array}$ & $\begin{array}{l}\text { Presentasi, tanya jawab, } \\
\text { workshop }\end{array}$ & $2 \times 45$ menit \\
\hline $\begin{array}{l}\text { Pemaparan dan praktik mendaringkan materi yang telah dibuat } \\
\text { dengan menggunakan iSpring }\end{array}$ & $\begin{array}{l}\text { Presentasi, tanya jawab, } \\
\text { workshop }\end{array}$ & $2 \times 45$ menit \\
\hline Evaluasi pelatihan & $\begin{array}{l}\text { Pembagian kuesioner, tabulasi } \\
\text { dan analisis }\end{array}$ & $1 \times 45$ menit \\
\hline Penugasan di rumah & $\begin{array}{l}\text { kerja mandiri dan konsultasi } \\
\text { bilamana diperlukan }\end{array}$ & 2 minggu \\
\hline
\end{tabular}

Untuk memperlancar pelaksanaan kegiatan pengabdian, tim pengabdi dan mitra berbagi tugas dan tanggung jawab. Mitra pengabdian, dalam hal ini adalah MGMP Bahasa Inggris MA Aliyyah Kabupaten Demak dilibatkan dan diberi tugas serta tanggung jawab. Mereka terlibat dalam perencanaan pelaksanaan program, bertugas, dan bertanggung jawab untuk sosialisasi dan koordinasi dengan para anggota MGMP, menyiapkan tempat pelatihan, melaksanakan pendaftaran peserta, terlibat dalam menyiapkan konsumsi, dan evaluasi pelaksanaan program. Yang juga penting adalah mitra terlibat dalam perencanaan program tindak lanjut karena tim pengabdi berharap akan ada kegiatan berkelanjutan. Secara lengkap, tugas dan tanggung jawab tim pengabdi dan mitra disajikan di Tabel 2.

Tabel 2. Tugas dan tanggung jawab tim pengabdi dan mitra

\begin{tabular}{lcc}
\hline \multicolumn{1}{c}{ Kegiatan } & Tim Pengabdi \\
\hline Merencanakan pelaksanaan program & $\mathrm{V}$.itra \\
Sosialisasi dan koordinasi MGMP & $\mathrm{V}$ \\
Menyiapkan materi pelatihan dan perlengkapan pelatihan. & $\mathrm{V}$ \\
Menyiapkan tempat pelatihan & - \\
Melaksanakan pendaftaran peserta & - \\
Menyiapkan konsumsi & $\mathrm{V}$ \\
Memberikan pelatihan, pembimbingan, dan pendampingan & $\mathrm{V}$ \\
Evaluasi pelaksanaan program & $\mathrm{V}$ \\
Perencanaan program tindak lanjut & $\mathrm{V}$ \\
\hline
\end{tabular}

\section{Jadwal kegiatan}

Kegiatan pengabdian dilaksanakan pada hari Sabtu 10 Oktober 2020 bertempat di Aula MA Negeri Demak JI. Diponegoro Kota Demak dari pukul 08.00 sampai dengan pukul 16.00 wib. Setelah itu kegiatan dilanjutkan dengan penugasan di rumah dan konsultasi secara daring. 
ABDIMAS: Jurnal Pengabdian Masyarakat Universitas Merdeka Malang

Volume 7, No 1, February 2022: 187-196

\section{HASIL DAN PEMBAHASAN}

Tim pengabdi memberikan pelatihan pembuatan bahan ajar menggunakan aplikasi iSpring kepada guru-guru yang tergabung dalam MGMP Bahasa Inggris Kabupaten Demak. Tiga puluh guru mendaftar dan hadir pada pelaksanaan kegiatan pada hari Sabtu 10 Oktober 2021. Seluruh peserta mengikuti pelatihan pembuatan bahan ajar dengan menggunakan aplikasi iSpring yang diintegrasikan kedalam Microsoft Power Point. Pelatihan dimulai dengan acara pembukaan yang diisi dengan sambutan oleh Ketua MGMP dan Ketua Tim Pengabdi sebagaimana didokumentasikan di Gambar 2. Ketua MGMP mengucapkan terima kasih kepada tim pengabdi dan berharap kegiatan kemitraan bisa dilaksanakan secara berkelanjutan. Ketua MGMP juga mendorong para guru untuk terus berbenah dan berinovasi sehingga kualitas pembelajaran daring yang dilaksanakan bisa berdampak optimal pada capaian belajar siswa. Pada sambutannya Ketua Tim Pengabdi menyampaikan pentingnya penyajian materi dalam pembelajaran daring. Para guru diharap mampu menyajikan materi sedemikian rupa sehingga bisa menarik perhatian siswa dan mendorong mereka terlibat dalam proses pembelajaran. Sajian materi yang menarik, interaktif, dan dinamis akan membantu mengikat (engage) siswa. Keterikatan siswa (student engagement) dalam proses pembelajaran perlu diupayakan secara optimal mungkin karena engagement berpengaruh pada capaian belajar (achievement) (Lei et al., 2018).

Acara kemudian dilanjutkan dengan install aplikasi iSpring ke dalam Microsoft Power Point di laptop peserta. Peserta dipandu untuk meng-install dan mengintegrasikan iSpring kedalam Microsoft Power Point. Kendala muncul ketika ada gawai atau laptop yang tidak memenuhi spesifikasi untuk mengintegrasikan iSpring ke dalam Microsoft Power Point. Setelah terintegrasi, peserta pelatihan kemudian berlatih mengoperasikan untuk membuat bahan ajar menggunakan template yang tersedia, membuat simulasi dialog, memasukkan rekaman tangkapan layar dan memasukkan video atau audio penjelasan materi, kemudian rangkaian materi tersebut ditutup dengan quiz sebelum didaringkan dalam sebuah tautan yang bisa dibuka oleh siswa kapan pun dan dimana pun tanpa perlu menyimpan file. Materi beserta penjelasan sudah bisa didapatkan dan bisa dibuka kapan pun juga tanpa membuat penuh memori gawai siswa. Pada tahap ini tampak jelas perlunya para guru melek teknologi, lebih khusus lagi melek ICT (ICT literate) (Bhattacharjee \& Deb, 2016).

Dalam situasi pandemi COVID-19, pelatihan dilakukan dengan mengikuti prosedur kesehatan pencegahan COVID-19. Pencegahan COVID-19 dengan 5M diterapkan dan dipatuhi dengan baik sebagaimana didokumentasikan di Gambar 3. Walaupun menggunakan masker dan jaga jarak, peserta mampu mengikuti semua rangkaian materi yang disampaikan serta berhasil mengerjakan tugas yang diberikan. Peserta pelatihan dapat mengikuti rangkaian kegiatan, termasuk praktik, dengan baik sampai dengan selesai. Tim pengabdi, dengan memperhatikan jarak aman, menjelaskan, mengarahkan, dan membantu peserta untuk bisa memahami dan menguasai materi dan keterampilan yang diberikan.

Pada sesi install aplikasi dan workshop, sebagaimana didokumentasikan pada Gambar 4, tim Pengabdi mendampingi, mengarahkan, dan membantu peserta sehingga mereka bisa melakukan apa yang diharapkan. Beberapa guru menguasai prinsip-prinsip dasar Power Point dan aplikasi sehingga mereka, hanya dengan sedikit penjelasan, sudah bisa membuat materi mata pelajaran yang diampu meskipun masih dalam bentuk yang perlu diedit dan ditata ulang. Sebagian yang lain, karena tingkat literasi ICT yang rendah, memerlukan pendampingan langkah per langkah. Hal ini menjadikan kegiatan pelatihan berjalan lambat. Kendala lain yang sangat dirasakan adalah ketersediaan akses internet cepat untuk seluruh peserta. Banyak waktu terbuang karena koneksi lambat dan putus nyambung.

Luaran pelatihan berupa pengetahuan, keterampilan, dan produk. Untuk pengetahuan, peserta bisa menjelaskan apa dan untuk apa aplikasi iSpring. Bagaimana mengintegrasikan aplikasi iSpring ke dalam Power Point untuk selanjutnya dipergunakan untuk membuat bahan pembelajaran daring. 
Peserta mengetahui langkah-langkah install aplikasi sampai dengan pengoperasian dan mendaringkan bahan pembelajaran sehingga bisa diakses siswa. Pada aspek keterampilan, mereka bisa melakukan install dan pengoperasian aplikasi untuk menyajikan bahan ajar yang diampu. Pada aspek produk, ada produk berupa bahan ajar pembelajaran daring yang dibuat dengan aplikasi iSpring. Karena sampai dengan akhir sesi pelatihan luring, belum ada peserta yang benar-benar menyelesaikan produknya, maka penyelesaiannya menjadi penugasan di rumah dalam waktu 2 minggu. Selama pengerjaan tugas tersebut, mereka bisa berkonsultasi dengan tim pengabdi secara daring.
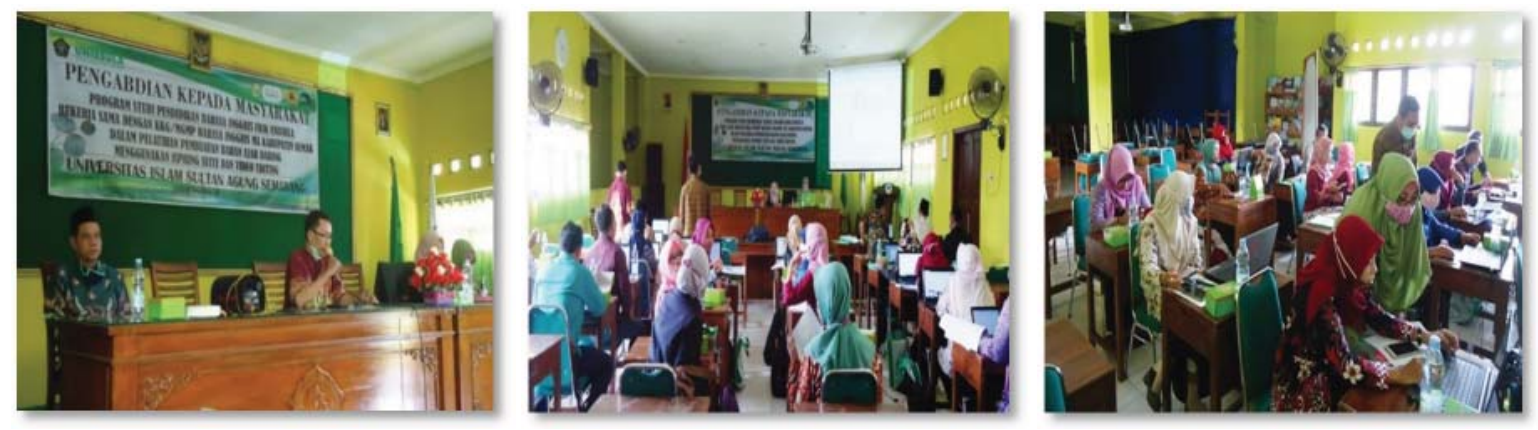

Gambar 2. Sambutan Ketua Tim Pengabdi dan Ketua MGMP di acara pembukaan pelatihan Gambar 3. Peserta menjaga jarak satu sama lain untuk menghindari penyebaran virus

Gambar 4. Tim pengabdi mendampingi dan membantu peserta

Di bagian akhir kegiatan pengabdian, dilakukan evaluasi berupa pemberian umpan balik dari peserta terkait dengan kegiatan yang telah dilaksanakan. Butir-butir pertanyaan evaluasi mengacu pada kuesioner pelatihan pembuatan presentasi Interaktif (Juanita et al., 2019) yang antara lain menyangkut bisa/tidaknya kegiatan pelatihan diikuti dengan baik, kemudahan materi, peran tutor, contoh dan latihan yang diberikan, dan kemanfaatan pelatihan. Hasilnya disajikan di Tabel 3.

Tabel 3. Evaluasi kegiatan oleh peserta

\begin{tabular}{lccccc}
\hline \multicolumn{1}{c}{ Item Evaluasi } & SS (\%) & S (\%) & R (\%) & TS (\%) & Jumlah \\
\hline Pelatihan bisa diikuti dengan baik & 3 & 80 & 10 & 7 & 100 \\
Materi pelatihan mudah dipahami & 7 & 73 & 10 & 10 & 100 \\
$\begin{array}{l}\text { Tutor menjelaskan dan menjawab pertanyaan dengan jelas dan } \\
\text { mudah dipahami }\end{array}$ & 4 & 72 & 14 & 10 & 100 \\
Tutor membantu peserta yang menghadapi kesulitan & 13 & 67 & 13 & 7 & 100 \\
$\begin{array}{l}\text { Contoh dan latihan yang diberikan bisa dikerjakan } \\
\text { Pelatihan bermanfaat untuk mengembangkan kemampuan }\end{array}$ & 3 & 83 & 7 & 7 & 100 \\
mengajar & 39 & 52 & 6 & 3 & 100 \\
\hline
\end{tabular}

Keterangan: $\mathrm{SS}$ = sangat setuju; $\mathrm{S}=$ setuju; $\mathrm{R}$ = ragu-ragu; $\mathrm{TS}$ = tidak setuju

Terkait dengan bisa/tidaknya pelatihan diikuti dengan baik, dari hasil kuesioner yang disebarkan diperoleh bahwa $80 \%$ peserta merespon "Setuju" pada pernyataan "pelatihan bisa diikuti dengan baik". Ini berarti mayoritas responden setuju bahwa pelatihan bisa diikuti dengan baik sehingga mudah bagi peserta dalam memahami materi yang disampaikan. Untuk materi pelatihan diperoleh data $73 \%$ peserta menjawab dengan pernyataan "Setuju" bahwa "Materi pelatihan mudah dipahami". Ini bermakna secara umum materi tidak sulit. Keterpahaman juga disebabkan oleh metode penyampaian materi. Dengan demikian disimpulkan metode penyampaian materi sudah sesuai dengan harapan peserta pelatihan. 
ABDIMAS: Jurnal Pengabdian Masyarakat Universitas Merdeka Malang

Volume 7, No 1, February 2022: 187-196

Dalam hal peran tutor menjelaskan dan menjawab pertanyaan, diperoleh data $72 \%$ peserta menyatakan "Setuju" pada pernyataan "Tutor menjelaskan dan menjawab pertanyaan dengan jelas dan mudah dipahami". Ini bermakna bahwa peran tutor telah cukup baik. Mereka bisa menjelaskan materi dan merespon pertanyaan dan kesulitan yang dihadapi peserta. Hasil kuesioner pada aspekaspek selanjutnya juga jelas menunjukkan bahwa pelatihan yang dilaksanakan diterima secara baik oleh peserta dan mereka puas dengan apa yang telah dilaksanakan. Evaluasi kemanfaatan pelatihan secara keseluruhan juga positif dimana 39\% peserta merespon dengan "Sangat setuju" dan 52\% menyatakan "Setuju" pada pernyataan "Pelatihan bermanfaat untuk mengembangkan kemampuan mengajar" yang bermakna bahwa pelatihan ini dapat meningkatkan keterampilan mereka dalam pembuatan bahan ajar daring.

Di luar hal-hal positif tersebut, perlu juga diketahui beberapa kendala yang terjadi. Di antaranya adalah kemampuan mengoperasikan laptop dari sebagian besar peserta yang perlu ditingkatkan. Beberapa peserta sepertinya menggunakan laptop hanya untuk menulis teks. Meski mereka telah memiliki perangkat tersebut sejak lama, mereka belum mengeksplorasi kemanfaatan perangkat ini secara optimal. Keterampilan-keterampilan dasar seperti mengolah dan menyajikan gambar, menambahkan suara (audio) masih perlu ditingkatkan. Hal kedua adalah ketersediaan layanan internet. Ketika para guru di sekolah, mereka bisa menggunakan internet secara gratis yang disediakan oleh sekolah, tetapi ketika di rumah, mereka tetap harus melakukan "penghematan kuota" karena terbatasnya anggaran yang tersedia. Studi terdahulu menunjukkan bahwa pengeluaran pembelanjaan layanan internet para guru meningkat lebih dari 100\% selama pandemi (Azhar, 2020). Yang ketiga adalah ketersediaan waktu bagi para guru untuk berkonsentrasi menyiapkan bahan ajar secara baik. Mereka menyampaikan waktunya telah habis untuk mengerjakan hal-hal rutin lainnya.

\section{SIMPULAN DAN SARAN}

Kegiatan pengabdian ini bertujuan meningkatkan kemampuan para guru yang tergabung dalam MGMP Bahasa Inggris MA Kabupaten Demak dalam membuat bahan ajar untuk pembelajaran daring. Hal ini dilakukan karena setelah pembelajaran daring berlangsung lebih dari satu semester, masih banyak guru yang melaksanakan pembelajaran daring hanya dengan ceramah dan penugasan materi dari buku sehingga pembelajarannya kurang bisa menarik minat dan motivasi belajar siswa. Aplikasi iSpring bisa digunakan untuk berinovasi dalam penyajian pembelajaran daring karena bisa memuat teks, suara (audio), dan gambar hidup (video) yang diintegrasikan dengan aplikasi Power Point. Dengan iSpring, teks, audio, video, dan quiz bisa disajikan secara lebih menarik dan interaktif yang bisa diakses siswa kapan saja. Kegiatan pelatihan yang berlangsung selama 1 hari secara luring di aula MA Negeri Demak dengan penerapan protokol kesehatan dan dilanjutkan dengan penugasan di rumah ini menghasilkan luaran pengetahuan, keterampilan, dan produk. Pemahaman guru mengenai aplikasi iSpring meningkat. Mereka juga secara bertahap mampu mengoperasikan aplikasi iSpring untuk pembuatan materi pembelajaran. Meskipun masih perlu perbaikan, mereka sudah bisa menghasilkan produk berupa materi pembelajaran daring pada topik mata pelajaran yang diampu. Secara umum peserta merasa puas dengan kegiatan ini dan menyatakan bahwa kegiatan pengabdian ini bermanfaat bagi mereka.

Untuk semakin memperdalam dan melatih kemampuan para guru dalam membuat perangkat pembelajaran daring yang menarik, efektif, dan efisien, perlu adanya kontinuitas dari kegiatan pelatihan yang berfokus pada aspek lainnya seperti pembuatan evaluasi pembelajaran baik yang formatif maupun summatif. Kerjasama yang baik antara Tim Pengabdi dengan MGMP bisa terus diupayakan agar mutu pembelajaran semakin membaik. 


\section{The development of capability to create online learning with i-Spring Application for English teachers}

Hartono Hartono, Nani Hidayati

\section{UCAPAN TERIMA KASIH}

Ucapan terima kasih kami sampaikan kepada: (1) Lembaga Penelitian dan Pengabdian kepada Masyarakat (LPPM) Universitas Islam Sultan Agung (UNISSULA) atas izin dan dukungannya sehingga kegiatan ini berjalan dengan baik; (2) Bapak Zainal Abidin, S.Pd., M.Si. selaku Ketua MGMP Bahasa Inggris MA Kabupaten Demak atas kesediaan menjadi Mitra dalam kegiatan pengabdian ini; (3) Para guru MGMP Bahasa Inggris MA Kabupaten Demak yang telah dengan tekun dan sungguh-sungguh mengikuti kegiatan pelatihan.

\section{DAFTAR PUSTAKA}

Anwar, M. S., Maseleno, A., Choirudin, C., Ningsih, E. F., \& Dewi, T. (2019). Developing an interactive mathematics multimedia learning based on iSpring presenter in increasing students' interest in learning mathematics. Al-Jabar: Jurnal Pendidikan Matematika, 10(1), 135-150.

https://doi.org/10.24042/ajpm.v10i1.4445

Arifa, F. N. (2020). Implementation challenges of learning from home policies in the emergency of COVID-19. Info Singkat A Brief Study of Actual and Strategic Issues, 12(7).

Azhar, A. (2020). Changes in cost incurred by Indonesian teachers for online training during COVID-19 pandemic. Populasi, 28(2), 18-31. https://doi.org/10.22146/jp.63344

Bhattacharjee, B., \& Deb, K. (2016). Role of ICT in 21 st century's teacher education. International Journal of Education and Information Studies, 6(1), 1-6.

Day, T., Chang, I. C. C., Chung, C. K. L., Doolittle, W. E., Housel, J., \& McDaniel, P. N. (2021). The immediate impact of COVID-19 on postsecondary teaching and learning. The Professional Geographer, 73(1), 1-13. https://doi.org/10.1080/00330124.2020.1823864

Fadillah, A., Bilda, W., Saleh, H., \& Yenni, Y. (2021). Design of interactive learning media in the COVID19 time using iSpring. Prima: Jurnal Pendidikan Matematika, 5(1), 1-10. http://dx.doi.org/10.31000/prima.v5i1.3260

Gillett-Swan, J. (2017). The challenges of online learning: Supporting and engaging the isolated Learner. Journal of Learning Design, 10(1), 20-30. http://dx.doi.org/10.5204/jld.v9i3.293

Hagerty, S. L., \& Williams, L. M. (2020). The impact of COVID-19 on mental health: The interactive roles of brain biotypes and human connection. Brain, Behavior, \& Immunity-Health, 5, 100078. https://doi.org/10.1016/j.bbih.2020.100078

Handayani, L. (2020). Keuntungan, kendala dan solusi pembelajaran online selama pandemi COVID19: Studi ekploratif di SMPN 3 Bae Kudus. Journal Industrial Engineering \& Management Research (JIEMAR), 1(2), 15-23. https://doi.org/10.7777/jiemar.v1i2.36

Jannah, M., Husna, A., \& Nurhalimah, S. (2020). Pembuatan aplikasi android dengan cepat menggunakan iSpring untuk menunjang pembelajaran secara daring. VEKTOR: Jurnal Pendidikan IPA, 1(2), 66-72. https://doi.org/10.35719/vektor.v1i2.8

Juanita, S., Pramusinto, W., \& Anif, M. (2019). Peningkatan sumber daya manusia pada Yayasan Ummah Mulia Bangsa di Tangeran dalam pemanfaatan internet sebagai media publikasi dan literasi informasi. In Seminar Nasional Multi Disiplin Ilmu dan Call for Papers, 978-979.

Kebritchi, M., Lipschuetz, A., \& Santiague, L. (2017). Issues and challenges for teaching successful online courses in higher education: A literature review. Journal of Educational Technology, 46(1), 4-29. https://doi.org/10.1177/0047239516661713 
ABDIMAS: Jurnal Pengabdian Masyarakat Universitas Merdeka Malang

Volume 7, No 1, February 2022: 187-196

Lei, H., Cui, Y., \& Zhou, W. (2018). Relationships between student engagement and academic achievement: A meta-analysis. Social Behavior and Personality: an international journal, 46(3), 517-528. https://doi.org/10.2224/sbp.7054

Lestiyanawati, R., \& Widyantoro, A. (2020). Strategies and problems faced by Indonesian teachers in conducting e-learning system during COVID-19 outbreak. LLiENT Journal (Journal of Culture, Literature, Linguistics and English Teaching), 2(1), 71-82. https://doi.org/10.32699/cllient. v2i1.1271

Nicola, M., Alsafi, Z., Sohrabi, C., Kerwan, A., Al-Jabir, A., Iosifidis, C., ... \& Agha, R. (2020). The socioeconomic implications of the coronavirus pandemic (COVID-19): A review. International Journalof Surgery, 78, 185-193. https://doi.org/10.1016/j.ijsu.2020.04.018

Prabowo, A. S., Conina, P. D. D., Afiati, E., \& Handoyo, A. W. (2020). Kesiapan guru dalam melaksanakan pembelajaran daring ditengah wabah COVID-19. Jurnal Penelitian Bimbingan dan Konseling, 5(2). http://dx.doi.org/10.30870/jpbk.v5i2.10107

Titi, L., \& Sumarni, W. (2020). Kendala pembelajaran daring selama pandemic COVID-19. In Prosiding Seminar Nasional Pascasarjana UNNES, 3(1), 286-291. 